$14^{\text {th }}$ Conf. Agric. Develop. Res., Fac. of Agric.,

Ain Shams Univ., March, 2019., Cairo, Egypt

Special Issue, 27(1), 691 - 697, 2019

Website: http://strategy-plan.asu.edu.eg/AUJASCI/

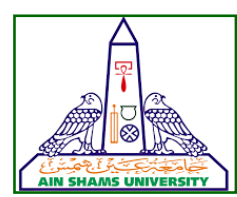

\title{
EFFECT OF MYCORRHIZAE AND DIFFERENT RATES OF NPK ON VEGETATIVE GROWTH AND YIELD OF TOMATO PLANT UNDER NORTH SINAI CONDITIONS
}

\author{
Hegazy $^{1}$, M.M.H., Abou El-Yazied ${ }^{2}$ A., Abd El-Gawad ${ }^{2}$ H.G. and Abd-Elbaset ${ }^{1}$ A. \\ 1. Plant Production Dept., Desert Research Center, Cairo, Egypt \\ 2. Horticulture Dept., Fac. of Agric., Ain Shams Univ., P.O. Box 68, Hadyek Shoubra11241, \\ Cairo, Egypt
}

*Corresponding author: mahegazynew@gmail.com

Received 14 November, 2018, $\quad$ Accepted 18 December, 2018

\begin{abstract}
The experiments were conducted to evaluate the effect of mycorrhizae (Glomus sp. and Gigspora sp.) application on the vegetative growth and yield of tomato plants (Alisa cultivar), and its relevance to the mineral fertilizers requirements as NPK during the seasons of 2015/2016 and 2016/2017. The experiments were conducted at Baloza Research Station, Desert Research Center, North Sinai Governorate, Egypt. The experimental design was a randomized complete block design with three replicates, every replicate included 4 treatments (75 and $100 \%$ of the recommended mineral fertilizer only or combined with the mycorrhizae treatment). The results showed that mycorrhizae application significantly increased the vegetative growth characters of tomato plant such as plant height, number of shoots, number of leaves, stem diameter, fresh and dry weights and yield. There were no significant differences in the vegetative growth characteristics of tomato plants receiving $75 \%$ of mineral fertilizers in addition to mycorrhizae application as compared with plants receiving $100 \%$ of mineral fertilizers only, except for the fresh weight of plants. The plants were received $100 \%$ of the recommended mineral fertilizers combined with mycorrhizae treatment gave the highest values of vegetative growth characters and yield. Therefore, we recommended that, using of mycorrhizae could be affective to maximize the utilization of mineral fertilizers, in addition, the mycorrhizea is ecofriendly, economically and consid-
\end{abstract}

ered as one of the most important bio-fertilizer resources.

Key words: Tomato, Vegetative growth, Yield, Mycorrhizae, Mineral fertilizers,

\section{INTRODUCTION}

Tomato (Lycopersicon esculentum Mill.) is an annual vegetable crop, the most popular vegetable all over the world, has great nutritional value due to its antioxidant contents such as lycopene and vitamin C (Clinton, 1998 and Kaur et al 2002). The nutrient management in organic farming is done through materials such mycorrhizae as a nitrogen source, the presence of mycorrhizae enhance plant productivity by the biological nitrogen fixation, phosphate solubilization, production of hormones and vitamins, and other growth factors required for plant growth (Bhattacharya et al 2000). On the other hand, some studies indicated that mycorrhizae may inhibit plant growth and nutrient uptake, which may be attributed to the presence of phytotoxins produced by some species of microorganisms which activated by application of mycorrhizae (Ramadan, 2007), lack of $\mathrm{No}_{3}$ concentration around the plant root lead to a decrease in the number of lateral roots and inhibit root hair elongation, thus weakening the root system (Mantelin and Touraine, 2004). Mycorrhizae is an environmentally friendly technique such as other biofertilizers not only reduces load of chemical fertilizers in the plants but also minimizes the pollution in the soil with such this substances (Abul Hossain, 
2012), application of mycorrhizae increases the number of microorganisms, while the application of chemicals can be harmful to the microorganisms in the soil (Khan et al 2000 and Bareisis et al 2002). Despite the high prices of mineral fertilizers and lack sometimes, almost all farmers are relying on commercial fertilizers without organic fertilizers for profitable yields, thus reduce the organic matter and affect chemical and physical properties of the soil (Zia et al 2000). Kumar and Sharma (2004) reported that using of mycorrhizae in combined with the mineral fertilizers i.e. nitrogen, phosphorus and potassium were found to be more beneficial for the tomato cultivation, where the yield and nutrient content increased. The integration between mineral fertilizers and Bio-fertilizers is very important, which plays a key role in sustain soil fertility and sustainable agriculture development. This study aims to evaluate the role of mycorrhizae application in improving the efficiency of applying mineral fertilizers and its impact on the vegetative growth of tomato plant under newly reclaimed lands.

\section{MATERIAL AND METHODS}

Field experiments were carried out at the experimental farm of Baloza Research Station, Desert Research Center, North Sinai, Egypt to study the influence of application of two species of mycorrhizae accompanying with different levels of mineral fertilizers NPK on tomato plant (Alisa cultivar), during two seasons (2015/2016 and 2016/2017), to determine the best treatment under new reclaimed lands conditions. Tomato transplants were obtained from New Star Company,
Egypt, and the bio-fertilizer agents (two species of mycorrhizae, Glomus sp. and Gigspora sp.) from Cairo Micro-Biofertilizers Unit, Faculty of Agriculture, Ain Shams University. The chemical analyses of the experimental soil and irrigation water are presented in Table 1. Tomato transplants (Alisa cultivar) were transplanted into the field in the first week of September during the two seasons. Agriculture has been cultivated on an area of $4200 \mathrm{~m}^{2}$ in open field in new reclaimed soil. The area of the experimental plot was $20 \mathrm{~m}^{2}$ consisted of one ridges, each ridge was $20 \mathrm{~m}$ length and $1 \mathrm{~m}$ width. The plant distance was $30 \mathrm{~cm}$ apart on one ridge. The experimental design was a randomized complete block with three replications, all replicate included 4 treatments as follow:

$\mathrm{T} 1-75 \%$ of recommended mineral fertilizer.

T2- $75 \%$ of recommended mineral fertilizer + mycorrhizae application.

T3- $100 \%$ of recommended mineral fertilizer (Control).

T4- 100\% mineral fertilizer + mycorrhizae application.

The treatment of mycorrhizae was applied to the planting of tomatoes during the preparation of the cultivation process. The method of drip irrigation was used with the addition of mineral fertilization with irrigation water as follows:

- NPK 19/19/19 + $1 \mathrm{Kg} \mathrm{Fe}+1 / 2 \mathrm{Kg} \mathrm{Zn}+1 / 2 \mathrm{Kg}$ $\mathrm{Mg}, 15$ days intervals.

- $4 \mathrm{Kg}$ nitrate $+2 \mathrm{Kg}$ nitrate $\mathrm{Mg}$ (3 times a week).

- $3 \mathrm{Kg}$ potassium + $1 \mathrm{Kg}$ MAP (once a week).

- $3 \mathrm{Kg}$ Calcium Nitrate (15 days intervals).

- 1 liter phosphoric acid (once a week).

- $500 \mathrm{~g} \mathrm{NPK}+100 \mathrm{~g}$ Small elements +200 $\mathrm{cm}$ Amino acids / 200 liters of water (15 days intervals).

Table 1. Chemical analysis of the experimental soil and irrigation water.

\begin{tabular}{|c|c|c|c|c|c|c|c|c|c|c|c|c|}
\hline & \multicolumn{4}{|c|}{$\begin{array}{c}\text { Soluble Cations } \\
\text { (meg/100g) }\end{array}$} & \multicolumn{4}{|c|}{$\begin{array}{l}\text { Soluble Cations } \\
\text { (meg/100g) }\end{array}$} & \multirow[t]{2}{*}{$\mathrm{pH}$} & \multirow{2}{*}{$\begin{array}{c}\text { EC } \\
\left(\mathrm{ds} / \mathrm{m}^{2}\right)\end{array}$} & \multirow[t]{2}{*}{ SAR } & \multirow[t]{2}{*}{ ESP } \\
\hline & $\mathrm{Ca}^{2+}$ & $\mathrm{Mg}^{2+}$ & $\mathrm{Na}^{+}$ & $\mathrm{K}^{+}$ & $\mathrm{CO}_{3}{ }^{2-}$ & $\mathrm{HCO}_{3}{ }^{-}$ & $\mathrm{Cl}^{-}$ & $\mathrm{SO}_{4}{ }^{2-}$ & & & & \\
\hline Soil & 10.1 & 5.2 & 13.2 & 1.1 & - & 5 & 14.4 & 10.2 & 7.89 & 2.95 & 3.30 & 3.48 \\
\hline 'Water & 8.2 & 3.5 & 13.9 & 0.43 & - & 6 & 15.2 & 4.8 & 7.23 & 2.6 & 5.75 & 6.73 \\
\hline
\end{tabular}

"Irrigation water source is El-Salam Conduit, North Saini, Egypt. 

tomato plant Under North Sinai conditions

\section{Studied characteristics}

After 65 days from transplanting, five plants per plot were randomly chosen to measure plant height, number of shoots/plant, number of leaves/plant and plant fresh and dry weight. Total yield of five plants (from the inner ridges) were recorded from each plot, the average weight of yield/plant was calculated and yield per feddan was calculated by multiplying the average yield per plant by number of plants per feddan. and were recorded NPK ratio in leaves.

Mineral nutrients were determined in the fifth mature leaf from the top of the plant at the fourth week after transplanting (pollination and young fruit stage). The samples were dried at $70{ }^{\circ} \mathrm{C}$ for $72 \mathrm{~h}$ according to (Great Britain, 1986). Wet digestion method was used for total nutrient analysis similar to the sulfuric acid and hydrogen peroxide digestion method described by Allen et al (1974). The content of macro-nutrients $(\mathrm{N}, \mathrm{P}, \mathrm{K})$ were determined as follows:

1. Total nitrogen was determined by Kjeldahl method according to Jackson, (1958).

2. Phosphorus content was determined colorimetrically using ammonium molybdate and ascorbic acid (Watanabe and Olsen, 1965).

3. Potassium content was determined photometrical using flame photometer Jackson (1958).

\section{Statistical analysis}

Data were subjected to Analysis of Variance (ANOVA) as described by (Gomez and Gomez, 1984). Means were compared according to Duncan's Multiple Range Test (Duncan, 1955). Differences at $P<0.05$ were considered significant.

\section{RESULTS AND DISCUSSION}

The data in Tables 2 and 3 show the vegetative growth parameters of tomato plants such plant height, number of leaves, number of shoots, stem diameter, and fresh and dry weights as affected by the application of mycorrhizae and mineral fertilizers levels. The application of $75 \%$ of recommend- ed mineral fertilizers leads to a significant decrease in all vegetative growth traits of tomato plant, while application of mycorrhizae beside $75 \%$ recommended mineral fertilizers led to a significant increase in all vegetative growth characteristics of tomato in both seasons. There were no significant differences in the vegetative growth characteristics of tomato plants which received $75 \%$ of mineral fertilizers with mycorrhizae application as compared with plants receiving $100 \%$ of mineral fertilizers only without the mycorrhizae treatment, except for the fresh weight of plants. The highest values of vegetative growth characteristics were recorded in tomato plants receiving $100 \%$ of recommended mineral fertilizers with mycorrhizal application in both seasons. Many studies have stated the positive impact of mycorrhizae application on plant growth performance (Schreiner, 2007, Jansa et al 2008, Pellegrino et al 2011, Ortas and Ustuner, 2014, and Ziane et al 2017).

Concerning the total yield mycorrhizal inoculation had a significant effect on tomato yield, which was greater in T4 treatment (100\% mineral fertilizer + mycorrhizae application), where recorded 24.6 and 22.3 ton/fed in 2015/2016 and 2016/2017 respectively, compared to $\mathrm{T} 1 \mathrm{(75 \%}$ of recommended mineral fertilizer) and T3 (100\% of recommended mineral fertilizer). Also, T2 (75\% of recommended mineral fertilizer + mycorrhizae application) was in the same trend with T4 where an increasing level of mycorrhizae significantly increased the fruit yield of tomato (Fig. 1).

The increase of vegetative growth and yield indicators values of tomato plants in the presence of mycorrhizae may be due to its role in enhancing the physical properties of soil and nitrogen fixation in soil (Waller et al 2005 and Ziane et al 2017), mycorrhizae has a role in protecting plants against abiotic stress conditions (Mrabet et al 2014).

Regarding to the NPK content in leaves of tomato plant, data in table 4 shows the highest content of nitrogen, phosphorus and potassium in leaves of tomato plant was observed by $100 \%$ mineral fertilizer combined with micorrhizae treatments, while it was no significant differences between others treatments. These results are in line with Dawa et al (2013). 
Table 2. Effects of mycorrhizae and mineral fertilizer treatments on plant height, number of leaves and number of shoots of tomato plant during 2015/2016 and 2016/2017 seasons

\begin{tabular}{|c|c|c|c|c|c|c|}
\hline \multirow{2}{*}{ Treatments } & \multicolumn{2}{|c|}{ Plant height $(\mathrm{cm})$} & \multicolumn{2}{c|}{ Number of leaves } & \multicolumn{2}{c|}{ Number of shoots } \\
\cline { 2 - 7 } & $2015 / 2016$ & $2016 / 2017$ & $2015 / 2016$ & $2016 / 2017$ & $2015 / 2016$ & $2016 / 2017$ \\
\hline T1 & $67.3 \mathrm{c}$ & $63.6 \mathrm{c}$ & $33.9 \mathrm{c}$ & $30.4 \mathrm{c}$ & $3.6 \mathrm{~d}$ & $3.1 \mathrm{~d}$ \\
T2 & $73.6 \mathrm{~b}$ & $68.3 \mathrm{bc}$ & $41.4 \mathrm{~b}$ & $37.2 \mathrm{~b}$ & $4.5 \mathrm{~b}$ & $3.9 \mathrm{~b}$ \\
T3 & $76.3 \mathrm{~b}$ & $70.3 \mathrm{~b}$ & $43.7 \mathrm{~b}$ & $39.3 \mathrm{~b}$ & $4.4 \mathrm{c}$ & $3.8 \mathrm{c}$ \\
T4 & $82.7 \mathrm{a}$ & $79.4 \mathrm{a}$ & $52.0 \mathrm{a}$ & $48.2 \mathrm{a}$ & $5.4 \mathrm{a}$ & $4.7 \mathrm{a}$ \\
\hline
\end{tabular}

T1: $\quad 75 \%$ of recommended mineral fertilizer $\quad$ T3: $100 \%$ of recommended mineral fertilizer (Control)

T2: $\quad 75 \%$ of recommended mineral fertilizer+ mycorrhi- T4: $\quad 100 \%$ mineral fertilizer + mycorrhizae application zae application

Table 3. Effects of mycorrhizae and mineral fertilizer treatments on stem diameter, dry weight and fresh weight of tomato plant during $2015 / 2016$ and $2016 / 2017$ seasons

\begin{tabular}{|c|c|c|c|c|c|c|}
\hline \multirow{2}{*}{ Treatments } & \multicolumn{2}{|c|}{ Stem diameter $\left(\mathrm{cm}^{2}\right)$} & \multicolumn{2}{c|}{ Fresh weight $(\mathrm{g})$} & \multicolumn{2}{c|}{ Dry Weight $(\mathrm{g})$} \\
\cline { 2 - 7 } & $2015 / 2016$ & $2016 / 2017$ & $2015 / 2016$ & $2016 / 2017$ & $2015 / 2016$ & $2016 / 2017$ \\
\hline T1 & $0.478 \mathrm{a}$ & $0.420 \mathrm{a}$ & $314 \mathrm{~d}$ & $310 \mathrm{~d}$ & $55.2 \mathrm{c}$ & $53.9 \mathrm{c}$ \\
T2 & $0.605 \mathrm{a}$ & $0.538 \mathrm{a}$ & $435 \mathrm{c}$ & $430 \mathrm{c}$ & $74.1 \mathrm{~b}$ & $75.5 \mathrm{~b}$ \\
T3 & $0.705 \mathrm{a}$ & $0.630 \mathrm{a}$ & $492 \mathrm{a}$ & $448 \mathrm{~b}$ & $75.8 \mathrm{~b}$ & $75.3 \mathrm{~b}$ \\
T4 & $0.753 \mathrm{a}$ & $0.685 \mathrm{a}$ & $533 \mathrm{a}$ & $529 \mathrm{a}$ & $89.6 \mathrm{a}$ & $89.0 \mathrm{a}$ \\
\hline
\end{tabular}

T1: $75 \%$ of recommended mineral fertilizer $\quad$ T3: $100 \%$ of recommended mineral fertilizer (Control)

T2: $75 \%$ of recommended mineral fertilizer+ mycorrhizae T4: $100 \%$ mineral fertilizer + mycorrhizae application application

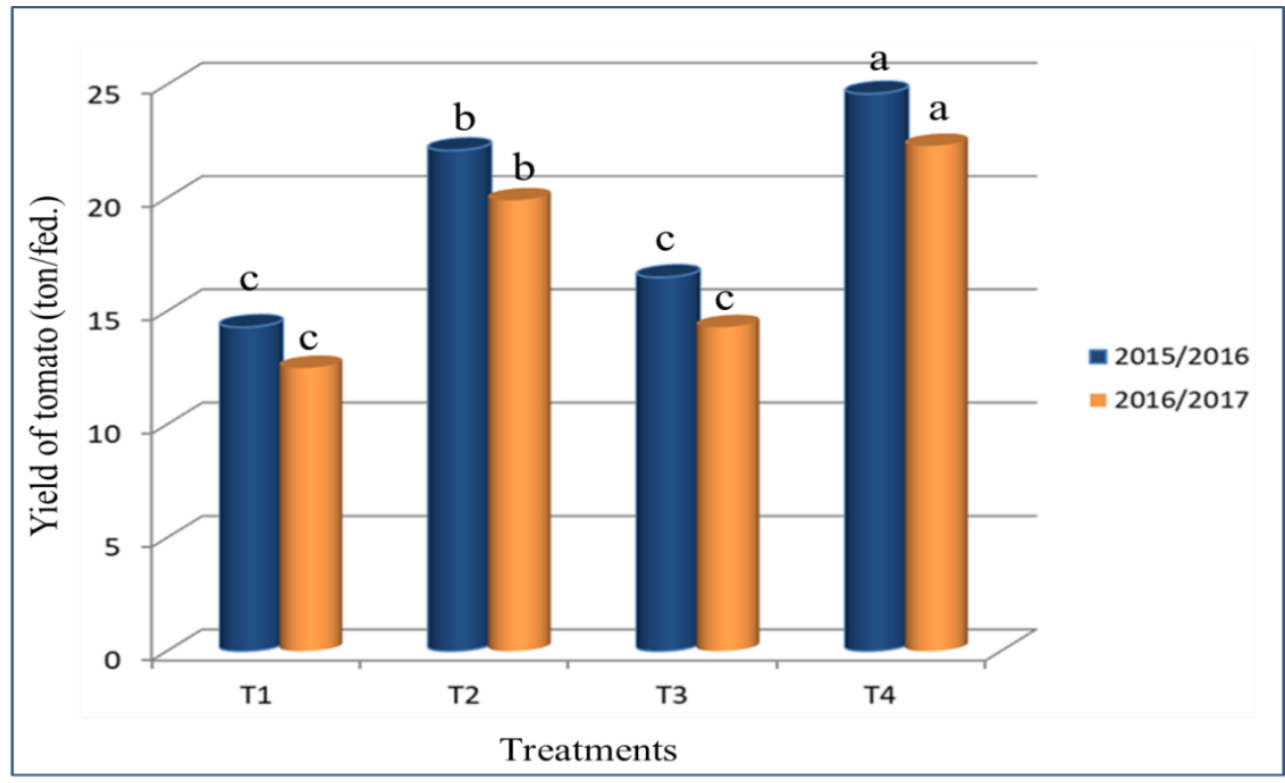

Fig. 1. Effects of mycorrhizae and mineral fertilizer treatments on Yield, of tomato plant during 2015/2016 and 2016/2017 seasons. (T1: $75 \%$ of recommended mineral fertilizer; T2: $75 \%$ of recommended mineral fertilizer + mycorrhizae application; T3: 100\% of recommended mineral fertilizer (Control); T4: 100\% mineral fertilizer + mycorrhizae application). 

tomato plant Under North Sinai conditions

Table 4. Effects of mycorrhizae and mineral fertilizer treatments on NPK in leaves of tomato plant during 2015/2016 and 2016/2017 seasons

\begin{tabular}{l|c|c|c|c|c|c|}
\hline \multirow{2}{*}{ Treatments } & \multicolumn{2}{|c|}{$\mathrm{N}(\%)$} & \multicolumn{2}{c|}{$\mathrm{P}(\%)$} & \multicolumn{2}{c|}{$\mathrm{K}(\%)$} \\
\cline { 2 - 7 } & $2015 / 2016$ & $2016 / 2017$ & $2015 / 2016$ & $2016 / 2017$ & $2015 / 2016$ & $2016 / 2017$ \\
\hline T1 & $1.74 \mathrm{c}$ & $1.56 \mathrm{c}$ & $0.29 \mathrm{~b}$ & $0.27 \mathrm{~b}$ & $2.03 \mathrm{~b}$ & $1.77 \mathrm{~b}$ \\
T2 & $2.25 \mathrm{~b}$ & $2.01 \mathrm{ab}$ & $0.35 \mathrm{a}$ & $0.33 \mathrm{a}$ & $2.07 \mathrm{ab}$ & $1.83 \mathrm{~b}$ \\
T3 & $2.16 \mathrm{~b}$ & $1.89 \mathrm{~b}$ & $0.33 \mathrm{ab}$ & $0.32 \mathrm{a}$ & $2.30 \mathrm{a}$ & $2.20 \mathrm{a}$ \\
T4 & $2.47 \mathrm{a}$ & $2.21 \mathrm{a}$ & $0.37 \mathrm{a}$ & $0.35 \mathrm{a}$ & $2.28 \mathrm{a}$ & $2.13 \mathrm{ab}$ \\
\hline
\end{tabular}

\section{Conclusion}

The results of the present study concluded that use of $100 \%$ of the recommended mineral fertilizer in combined with mycorrhizae application (Glomus $\mathrm{sp}$. and Gigspora sp) has led to improved plant growth and increased the values of vegetative growth parameters of tomato plant and yield increased significantly. An increasing level of mycorrhizae also significantly increased the fruit yield of tomato. Therefore, we recommend the use of mycorrhizae to maximize the utilization of added mineral fertilizers.

\section{REFERENCES}

Abul Hossain, M., Hagque M.M., Haque M.A. and G.N.M. Ilias, 2012. Trichoderma-Enriched Biofertilizer Enhances Production and Nutritional Quality of Tomato (Lycopericon esculentum Mill.) and Minimizes NPK Fertilizer Use. Agric. Res., 1(3), 265-272.

Allen, S.E., Grimshaw H.M., Parkinson J.A. and Quarmby C., 1974. Chemical analysis of ecological materials. Blackwell Scientific Publications, Oxford, UK, 565 p.

Bhattacharya, P., Jain, R.K. and Paliwal, M.K. 2000. Biofertilizers for vegetable. Indian Hort. 12-13.

Bareisis, R., Sniauka P. and Viselga G., 2002. Investigation of ecological potato cultivation possibilities.Progressive eco-frindly technological processes in agricultural engineering. Proceedings of the international conference raudondvaris. Lithuania 57 (66), 221-222.

Clinton, S.K.1998. Lycopene: Chemistry, biology and implications for human health And disease. Nutr. Rev., 56(2), 35-51.

Dawa, Kawsar K.A., Al-Gazar T.M. and AbdelFatah, A.M. 2013. Effect of chicken manure combined with bio-fertilizers mineral fertilizer and some foliar aplications on: 1- Vegetative growth and some chemical constituents of tomato leaves. J. Plant Production, Mansoura Univ., 4 (10), 1555 - 1570.

Duncan, D. B. 1955. Multiple ranges and Multiple F test. Biometries, 11, 1-42.

Gomez, K.A. and Gomes A.A..1984. Statistical Procedures for Agricultral Research. $2^{\text {nd }}$ Ed. John Wieley \& Sons, New York, USA.

Great Britain, Ministry of Agriculture, Fisheries and Food, 1986. The Analysis of Agricultural Materials- A Manual of the Analytical Methods used by the Agricultural Development and Advisory Service (ADAS)/Ministry of Agriculture, Fisheries and Food. 3e Reference book 427. London. HMSO

Jackson, M.L. 1958. Soil chemical analysis. Verlag: Prentice Hall, Inc., http:// doi.org/10.1002/ Jpln19590850311).

Jansa, J.L., Smith, F.A. and Smith S.E. 2008. Are there benefits of simultaneous root colonization by different Arbuscular mycorrhizal fungi?. New Phytol., 177, 779-789.

Kaur, R., Savage G.P. and Dutta P.C., 2002. Antioxidants Vitamins in four commercially Grown tomato cultivars. Nutr. Soc. Newzealand, 27, 69-74.

Khan, V.A., Stevens C., Wilson M.A., Brown J.E., Collins D.J., Lu J.Y. and Rhoden E.G. 2000. Evidence of rhizobacteria changes associated with the increase growth response of vegetables grown in agrimulch systems. J. Vegetable Crop Production. 6 (1), 53-73.

Kumar P. and Sharma, S.K. 2004. Integrated nutrient management for sustainable cabbagetomato cropping sequence under mid hill conditions of Himachal Pradesh. Indian J. Hortic. 61(4), 331-334.

Mantelin and Touraine. 2004. Plant growthpromoting bacteria and nitrate availability: im- 
pacts on root development and nitrate uptake. J. Experimental Botany, 55(394), 27-34.

Mrabet, S., Ouahmane, L., Mousadik, A., Msanda, F. and Abbas, Y., 2014. The Effectiveness of Arbuscular Mycorrhizal Inoculation and BioCompost Addition for Enhancing Reforestation with Argania spinosa in Morocco. Open Journal of Forestry, 4, 14-23.

Ortas, I. and Ustuner O., 2014. The effects of single species, dual species and indigenous mycorrhiza inoculation on citrus growth and nutrient uptake. Eur. J. Soil Biol., 63, 64-69.

Pellegrino, E., Bedini S., Avio L., Bonari E. and Giovannetti M. 2011. Field inoculation effectiveness of native and exotic arbuscular mycorrhizal fungi in a Mediterranean agricultural soil. Soil Biol. Biochem., 43, 367-376.

Ramadan, M.A.E. 2007. Behaviour of trace elements in soil and two varieties of tomato under different rates of fertilizers with and without biofertilizer. J. Appl. Sci. Res 3 (11), 1637-1645.

Schreiner, R.P. 2007. Effects of native and nonnative arbuscular mycorrhizal fungi on growth and nutrient uptake of 'Pinot noir' (Vitis vinifera L.) in two soils with contrasting levels of phosphorus. Appl. Soil. Ecol., 36, 205-215.

Waller, F., Achatz B., Baltruschat H., Fodor J., K. Becker, M. Fischer, T. Heier, R. Hückelhoven, Neumann, C., von Wettstein D., Franken P. and Kogel, K. 2005. The endophytic fungus Piriformospora indica reprograms barley to salt-stress tolerance, disease resistance, and higher yield. Proceedings of the National Academy of Sciences, 102 (38), 13386-13391.

Watanabe, F.S and Olsen S.R. 1965. Test of ascorbic acid method for determining phosphorus in water and $\mathrm{NaHCO}_{3}$ from soil. Sci. Soc. Am. Proc. 29, 227-278.

Zia, M.S., Mann R.A., Aslam M., Khan M.A., Hussain F. 2000. The role of green manuring in sustaining rice-wheat production. In: Proc. Symp. "Integrated Plant Nutrition Management", NFDC, Islamabad, pp. 130-149.

Ziane Hana, Amel Meddad-Hamza, Arifa Beddiar and Silvio Gianinazzi 2017. Effects of arbuscular mycorrhizal fungi and fertilization levels on industrial tomato growth and production. Int. J. Agric. Biol., 19, 341-347 
المؤتمر الرابع عشر لبحوث التنمية الزراعية،

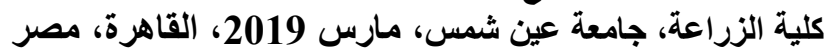

مجلا(27)، عدد (1)، عدد خاص مارس، مارس

Website: http://strategy-plan.asu.edu.eg/AUJASCI/

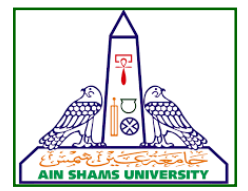

\section{تأثير الميكروهيزا ومستويات التسميد المعدني علي نمو ومحصول الطماطر تحت ظروف شمال سيناء}

$$
\begin{aligned}
& \text { محمود محمد حامد حجازي1" - أحمد ابو اليزيد2- هانى جمال عبد الجواد_- اشرف عبد الباسط1 }
\end{aligned}
$$

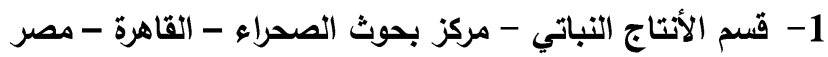

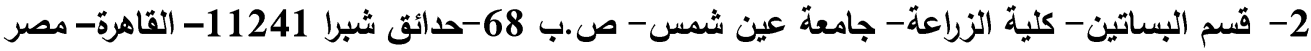

"Corresponding author: mahegazynew@gmail.com

Received 14 November , 2018,

Accepted 18 December, 2018

قطر الساق، الوزن الطازج والجاف للمجموع الخضري)

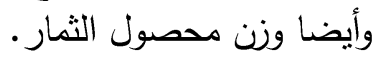

بينما أثنارت النتائج الي عدم وجود فرون فروق معنوية

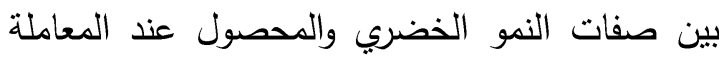

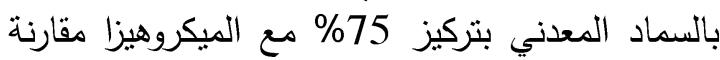

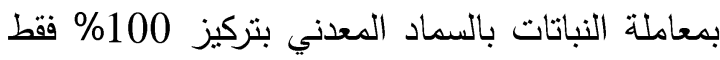

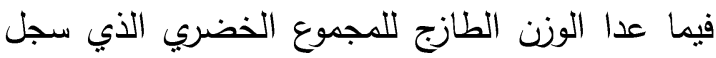
فروقا معنوية بين المعاملتين.

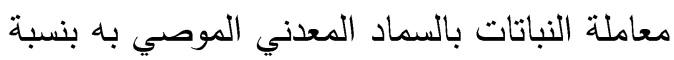

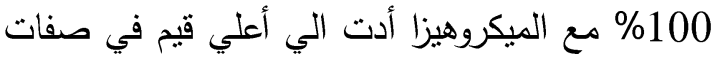

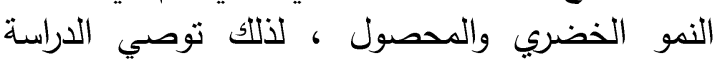

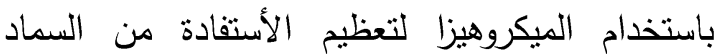

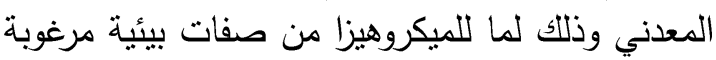

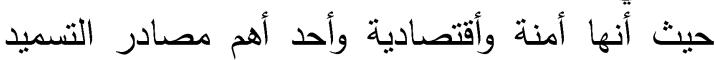

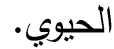

الكلمات الدالة: الطماطم، النمو الخضري، الميكروهيزا، التسميد المعدني.

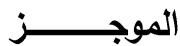

تم اجراء عدة تجارب لتقييم تأثير المعاملة

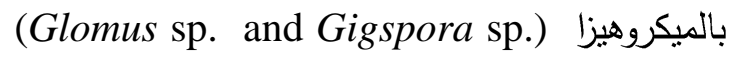
علي نمو نباتات الطماطم (صنف ألبسا)، والإحتياجات

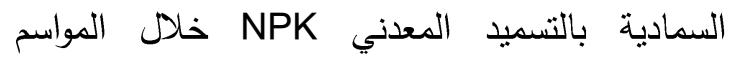
الزراعية 2016/2015، 2017/2016، بمحطة بحوث بالوظة التابعة لمركز بحوث الصحراء بمحافظة شمال سيناء، مصر وتمت الزراعة علي مساحة 4200 م2 في الأرض المكثوفة والتربة رملية جديدة.

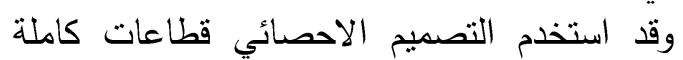
العشوائية في ثلاث مكررات لكل معاملة. حيث اثتنملت

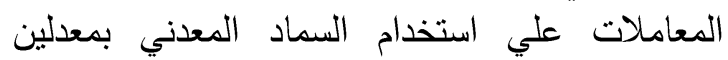
75، 100\% فقط من الموصي بهاب، ومعاملة

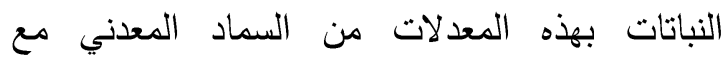
الميكروهيزا. وأثنارت النتائج أن المعاملة بالن الميكروهيزا

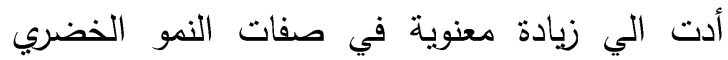
للنباتات (ارتفاع النبات، عدد الأفرع، عدد الأوراق، لأنوري 